\title{
Comments
}

\section{POPULATION CONTROL: THE LEGAL APPROACH TO A BIOLOGICAL IMPERATIVE}

Nearly every major economic or social problem today, whether national or international, can be shown to have a causal link with the unprecedented increase in human numbers which has gone unchecked since the Industrial Revolution. Increasing awareness of the implications of this uncontrolled growth, as well as dissatisfaction with present overcrowding, has raised the possibility of governmental regulation in family size in the future. This Comment examines the arguments in favor of such regulation and analyzes possible conflicts with presently existing constitutional restrictions of government power.

Environmental quality has become an issue of great concern to Americans, for while we have achieved a level of material affluence heretofore unknown to man, the environment we depend upon for life itself is suffering the effects of our industrial growth. For a variety of reasons ${ }^{1}$ it is imperative that we explore the causes of environmental deterioration and find solutions to the problems mvolved. This Comment will focus on population growth as a major link in the causal chain of environmental deterioration.

At the outset it is necessary to clarify several common misunderstandings surrounding the emotionally charged area of environmental problems and population growth. First, the critical issue most commonly called "population control" is not whether the number of human beings shall be limited, but how the limitation should occur. ${ }^{2}$ More pre-

1. The most widely accepted reason is simply that if these problems are not solved and man does not learn to live in harmony with nature, he will eventually be unable to exist, for the environment will not support him. This may be termed the ecological argument. A second reason is that man will have a better life in an onvironment full of beauty and diversity than in a monotonous, dirty environment typified by many of our cities. This is the aesthetic argument. A third justification for restoring the quality of the environment is based on the premise that while man may have the power to alter his natural surroundings (including the power of life and death over other species of animals) he does not necessarily have a right to do so. This may be called the moral argument. See Bates, The Human Ecosystem, in Resources AND MAN 21 (1969).

2. The finite size of the earth, as graphically deinonstrated in photos froin the recent Apollo missions, assures that man's numbers cannot increase indefinitely. The real questions are how and when the limitation shall occur. For further discussion 
cisely, since fluctuations in the size of man's population are a function of two variables-births and deaths-and since population growth is caused by a greater number of births than deaths over a given period, ${ }^{3}$ control of that growth could be achieved by decreasing the number of births, by increasing the number of deaths, or by any combination of increases or decreases in these two factors which would make the number of births and deaths equal. Thus a great famine or other environmental catastrophe would serve to control population with equal effectiveness and with greater speed than any birth control program.

This situation emphasizes the need to decide upon the goals we are seeking to achieve. This is a inost difficult task because of the diversity of values held by the inhabitants of the world coinmumity or even of our own society itself. Still it is possible to posit some goals by virtue of their wide acceptance throughout man's history. One such goal is the prevention of disease, famine and other causes of suffering and death. Further than mere prevention of death there is some standard of minimum comfort which can be established as a goal for every human being. This Comment assumes that this minimum standard includes an adequate diet, a supply of reasonably clean ${ }^{4}$ water to drink, reasonably clean air to breathe, and decent (but not necessarily elaborate) liousing. Many other items could be added, but for purposes of this discussion they are omitted since differing values would be placed upon them by different mdividuals. While the same is to some extent true of the above items, their purpose for now is simply to demonstrate the kinds of ultimate goals ${ }^{5}$ mankind should consider in facing the problem of deterioration of the enviroument and in evaluating recommendations for fertility control. ${ }^{\mathrm{B}}$

Finally, any goals which may be established are complicated by the notion that our present society owes something to the future inhabitants

of the limits of our resources, see P. EHrLich \& A. Ehrlich, Population, Resources, ENVIRONMENT 51-65 (1970).

3. See id. at 8.

4. The term "reasonably clean" betrays the lack of clear definition in our goals, but this particular goal, at least, can be defined by standards requisite to the prevention of disease and death.

5. These concepts can be lumped together under one generic term: the enhancement of the quality of human life. Unfortunately, not only is this goal vague, but so is the amount of improvement obtained for any particular action taken. But despite the lack of well-defined lines, if definite trends can be discerned-for example, increasing population means pressure on scarce resources which suggests future environmental problems-available options can be identified and this learning is necessary in making intelligent decisions both as individuals and as a community.

6. The term "fertility control" is used here rather than "population control" because control of births is the only form of population control which is compatible with the goal of limiting inortality. 
of the planet. This concept is difficult to deal with since knowledge of what the future will bring is unclear. Perhaps this idea must be rejected. But if it is not, there is the further difficulty of defining that duty and determining how far it extends. In either case, a discussion of population, resources, and the environment must come to grips with this notion.

POPULATION GROWTH: A THREAT TO MAN

\section{A. Population Growth and Resource Depletion}

Man has been endowed with a world rich in natural resources. In general, these resources may be classified as renewable and nonrenewable. An example of a renewable resource is the fertile soil on which we grow a large part of our food. With proper care, the soil will yield food harvests indefinitely. An example of a non-renewable resource is oil. Once burned it is gone, and thus one of the main technological problems man faces constantly is the discovery of new stocks of resouces to substitute for the diminishing supplies of non-replaceable resources.

Wise use of resources, then, requires man to preserve renewable resources by proper use; in essence, to treat the body of resources as the corpus of a trust, being careful to extract only the income therefrom; and to make existing supplies of non-renewable resources last as long as possible in order to have maximum time to find substitutes. Population growth produces pressures for renewable resources to yield more; until a point is reached where it is necessary to "invade principal" to sustain the population. The end result is a smaller amount of principal with which to produce the needed income. ${ }^{7}$ Non-renewable resources are also consumed faster, leaving less time in which to find substitutes and increasing the risk that man will find himself without certain necessities in the future. Reducing the standard of living for Americans

7. This analogy is a simplification of a very basic lesson of ecology. A biological system is an amazingly complex web of interactions among different organisms and betwecn those organisms and their physical surroundings. The more complex the system, the more stable it is likely to be, for each organism can rely on a variety of sources for food and other necessities. Thus if one species suffers due to some outside influence, the entire system will not change drastically. Man has a tendency to simplify ecosystems in order to make cfficient use of them for his own needs. He plants one crop in a large area and fimds it necessary to use pesticides to control competing organisms since there are no natural predators in the system to keep the insect population under control. Then he finds that the pesticides may be harming the environment by poisoning fish, birds, and even men. Perhaps man is demanding too much of the agricultural lands now: simplifying the system to the point of invading principal today at the price of lower sustained yield in the future. See P. EHRLrCH, THE Population Вомв 51-53 (1968); Bates, supra note 1, at 21, 26. 
would conserve a significant amount of resources, ${ }^{8}$ but this would not provide a final solution. ${ }^{9}$ Also, the assumption that the market mechanism will automatically adjust consumption to provide for man's future needs is imvalid. Unfortunately the market mechanism is not as perfect as Adam Smith ${ }^{10}$ envisioned it to be:

[T]here are questions to which the market does not yet know how to react ... and other questions concerning relationships that are expected to exist sufficiently far into the future so that they produce no signals in the narketplace of today. . . . Where scarcity of particular resources may become limiting, the question is whether the market will react far enough ahead to provide time for substitutes to be sought or technological solutions to be devised . . . .11

Even when the market does react to a future need, there is no guarantee that our technology will be capable of filling the need in time. "[I]n practice there is not one technological world but many, and . . . to extrapolate from experience in one area to expectations in another is hazardous."12 Excessive population also speeds resource depletion by destroying resources through pollution. ${ }^{13}$ Air pollution from automobile exhaust and industry damages plant-life ${ }^{14}$ and can be fatal to animals, including human beings. ${ }^{15}$ Water pollution, in a tremendous va-

8. See R. RIENOW \& L. RIENOW, MOMENT IN THE SUN 3-8 (1967).

9. It is clear that a larger number could be sustained at lower levels of subsistence. But if the population continues to increase, the end result will only be delayed. In addition this is probably not considered an acceptable goal by most Americans used to a relatively high standard of living; and from a practical point of view, poverty is probably not compatible with the careful planning which would be necessary for our society to hive in harmony with nature.

10. A. SMTth, Wealth OF Nations 1-5 (1776).

11. Chapman, Interactions Between Man and His Resources, in ResouRces AND MaN 31, 38 (1969).

12. Id.

13. Pollution is certainly also attributable to factors other than population growth. But the fact remains that pollution is not a problem when there are few enough people that the air and waters can adequately dilute the relatively small amount of waste produced. For an historical example see the discussion of air pollution in Los Angeles in P. Enrlich \& A. Ehruich, supra note 2, at 124-26. As population grows, these wastes must be specially treated in order to assure air and water supphes clean enough for human consumption, and the costs of sucl treatment today are very high. As these costs increase so does the risk that government officials will take the path of least resistance by lowering air and water quality standards rather than spending large sums of unoney to provide the technological facilities necessary to maintain the air and water at present quality. This knotty problem is a direct result of refusal to cope with the root of the problem-population growth. See generally Perlman, How Many People Will Kill the Earth, S.F. Chronicle, Dec. 30, 1969, at 1, col. 6.

14. Peet, We're Gassing Our Trees, AM. Forests, July, 1968, at 23; Machta, Winds, Pollution, and the Wilderness, THe LIVING WIIDERNESs, Summer 1969, at 3.

15. See, e.g., S.F. Chronicle, Nov. 12, 1969, at 15, col. 4. 
riety of forms, ${ }^{16}$ is destructive to fish, land animals, and phytoplankton. ${ }^{17}$

Thus the generality may be made painfully simple: We live in a world of limited resources, and population growth speeds the use, and in soine cases the destruction, of those resources. If population growth continues, then despite reductions in affluence, technological innovations, and increased expenditures for waste treatment, the population will eventually reach a point where there will not be sufficient resources to sustain any additional lruman beings. At this point population growth will cease. If fertility has not come down, mortality will in. crease.

If man wishes to prevent such a rise in mortahity, however, he cannot wait until he reaches the brink of disaster before controling fertility. One reason is that to do so would require a large expenditure of the principal sum of renewable resources as referred to above. By the time man reaches the point where further expenditure of principal to sustain the population is unfeasible, the amount of principal remaining would be too small to produce sufficient income for a population which for some time has utilized both income and principal. The result of waiting too long before controlling fertility would thus be a natural form of population control-massive increases in mortality.

There are alarming indications that man has already begun to imvade principal with respect to some critical renewable resources. One example is our ever-mcreasing dependence on pesticides so that our agricultural production can keep pace with population growth. ${ }^{18}$ Many of these pesticides remain active for years and accumulate in the tissues of animals, including human beings. ${ }^{19}$ Yet pesticides cannot now be

16. A few of the most noticeable are industrial wastes, phosphorus from detergents, untreated sewage, and pesticide runoff.

17. Phytoplankton are tiny one-celled organisms which live in vast quantities near the surface of the ocean. They produce oxygen through photosynthesis and provide food for larger species by their unique ability to convert solar energy into chemical potential energy. Thus destruction of these organisms necessarily decreases the size of a very important renewable resource-fish as food from the sea. See P. EHrich, supra note 7 , at 56-57.

18. See R. Rienow \& L. Rienow, supra note 8, at 195-214. Between 1940 and 1966, use of synthetic pesticides increased eight fold. Id. at 195. During that period, pesticide residues diffused throughout the biosphere: "[T] hey are now found not only in the flesh of isolated savage tribes (who did nothing to deserve them), but even in arctic penguins, seals, and in the flesh of fish that live 100 miles out in the seal" Id. at $200-01$.

19. The Rienows points out that while we know the most about the dangers of DDT because we have been using it longest, the newer poisons, such as endrin, dieldrin and chlordane are even more toxic-yet our iguorance of their long-term effects allows them to be used now while DDT holds the public's attention. Id. at 201. The problem is intensified by the cumulative effect of the pesticides: the chemicals freely cross the placenta from mother to unborn child. See P. EhrLich \& A. EHruich, 
abandoned because their use in the past has eradicated many natural enemies of agricultural pests. ${ }^{20}$ The prospect of continually accelerating dependence on these products is hardly reassuring. ${ }^{21}$ For while the exact point in time when the effect of this slow poisoning of the environment reaches critical stages cannot be determined, it is clear that if pesticide use continues to increase, as it seemingly must so long as population increases, the end result will be massive mortality. The most alarming realization is that it is almost impossible to determine whether it is not already too late. ${ }^{22}$

\section{B. Population Growth Through History}

Throughout most of man's history, population growth was very slow and rather steady when viewed in long range perspective. ${ }^{23}$ In general, fertility was fairly high but net population imcrease was held in check by war, famine, and disease which occurred sporadically, thus allowing an increase for a while followed by a sudden decrease to soine point slightly above that of one or two centuries previous. ${ }^{24}$ The Industrial Revolution, however, brought a great increase in scientific knowledge, whicls gradually lowered the incidence of large epidemics. ${ }^{25}$ Also, at least in the developed world, famine was all but eliminated. ${ }^{26}$ With mortality rates reduced to low levels, the populations of industrial nations such as the United States grew very rapidly for a few generations. ${ }^{27}$ As society became industrialized, the large family became less popular, with the result that the fertility rate dropped, slowing the rate of population increase. ${ }^{28}$ But it should be noted that the Umited States

supra note 2 , at 132 . Thus each new-born infant begins life with the dose her mother had, and when she reaches adulthood, has a much larger amount to pass on to her child.

20. R. RIENow \& L. RIENow, supra note 8, at 196. The use of DDT over the past 25 years has already caused the virtual extinction of several bird species. See P. EhrLich \& A. EhrLich, supra note 2, at 172.

21. The Rienows estimate that by 1975 use of synthetic pesticides will grow to four times what it was in 1966 or about $30^{\circ}$ times the figure for 1940. R. RIENow \& L. RIENow, supra note 8, at 195-96.

22. See P. EhrLich \& A. EHRLICH, supra note 2, at 180-81 for further discussion of the effect of pesticide use on the renewable resource, soil.

23. See W. Thompson, Population Problems 382-400 (1965).

24. Id.

25. Id. at 401-30. For another detailed history of world population growth see The Determination and Consequences of Population Trends, U.N. Doc. ST/SOA/Ser. $\mathrm{A} / 17$, at 5-20 (1953).

26. See W. ThOMPSON, supra note 23 , at 401-30 (1965).

27. Id.

28. Keyfitz, United States and World Populations, in Resources AND MaN 43, 52 (1969). 
has not stopped growing, ${ }^{29}$ nor has any other developed nation. ${ }^{30}$

In developing countries the situation is much worse. Fertility has remained high in the absence of the changes in social structure that industrialization produced in the United States. ${ }^{31}$ At the same time nuortality in developing countries has dropped sharply since World War II because developed nations have exported inortality reducing tecl1nology - antibiotics, insecticides, low cost sanitation methods, and pubhic health organizations-to thein. ${ }^{32}$ As a consequence, nost of these nations, unable or unwilling to control fertility, have experienced enormous growth rates which have greatly impeded their atteinpts to industrialize. $^{33}$ The present relationship between developed and developing

29. There is a tendency among laymen to confuse trends in the growth rate with fluctuations in absolute population size. Even during the Depression when the growth rate fell almost to one-half percent per year, the absolute size of the population continued to increase and has never in any year actually decreased. For the statistics showing yearly population growth in the United States from 1790 to 1957 , see U.S. BUREAU of the Census, Historical Statistics of the United States, Colonial Times to 1957, at 7 (1960). For the years 1958 to 1967 see Statistical Office of the U.N., Demographic Yearbook of 1967, U.N. Doc. E/F. 68.XIII.1, at 126 (1968).

Nathan Keyfitz explains that fluctuating growth rates inake prediction of future population size very difficult and that in the past, predictions based on trends in growth rates have been inaccurate because of later unexpected changes in growth rate trends. Keyfitz, supra note 28, at 43-45. A conservative (or optimistic) estimate of future growth in the United States is that in 1970 the figure 205 million will be reached; in 1985, 251 million; and in 2000, 304 million. Id. at 57. Thus while the growth rate may seem low (around one percent per year) the addition of 100 million people will be the result in the next 30 years unless the growth rate falls fairly rapidly. Although the growth rate in the United States declined in the late 1960's, there is reason to believe it may rise again as the large class of women born in the post-war "baby booin" inove through their childbearing years. See P. EHRLICH \& A. EHrLICH, supra note 2, at 33.

30. The statistics for the years 1959-68 show that none of the developed countries of Europe have experienced anything but continued increase in population size. See Statistical Office of the U.N., Monthly Bulletin of Statistics 1-4, Nov. 1969. One country that is often cited as having controlled its population through legalized abortion and wide dissemination of contraceptive knowledge and devices is Japan. See U.S. News \& WoRLd REP., Aug. 7, 1961, at 66; Chapin, Japan's Birth Rate-The Trend Turns, N.Y. Times, Oct. 25, 1964, \& 6 (Magazine), at 44. But despite all the optimistic reports, Japan's population is still growing fast enough to double im a little over 60 years. In 1966 the birth rate took a spectacular plunge in Japan, but 1966 was the year of the Fire Horse in which, according to widespread superstition, it is unfortunate to have a daughter for she will nuake a poor wife. N.Y. Tines, Dec. 29, 1967, at 11, col. 1. In 1967 and 1968, the growth rate was back up to pre-1966 lcvels of slightly over one percent per year. See Bureau of Statistics, OfFice of the Prime Minister, StaTISTICAL HANDBOOK OF JAPAN 16-17 (1969).

31. A. Coale \& E. Hoover, Population Growth and Economic DevelopMENT IN LOW INCOME COUNTRIES 15-17 (1958).

32. Id.

33. Populations in developing nations are doubling every 20 to 35 years. Therefore in order to maintaim the same low standard of living which their population currently enjoys, developing nations have to double the nation's food supply, power supply, edu- 
nations is one of growing strain since the gap between them in per capita income and wealth is widening. ${ }^{34}$ The population trends above described are in large ineasure responsible for this gap.

The most alarming side of this history is the fact that so little time is now required for the earth's population to generate a large number of people, each of whom makes demands upon the earth's finite carrying capacity. With approximately three and one-half billion inhabitants and a growth rate of only two percent, ${ }^{35}$ a population the size of the current United States population could be generated in just three years. While the Umited States' growth rate is only around one per cent, ${ }^{36}$ when applied to a population of 200 million, only slightly over 30 years are required to produce another 100 million people. Simce it was around 1915 when the United States' population reached 100 million, ${ }^{37}$ we can compare the past 50 years we have had to plan for the accomodation of our second 100 million. Considering our present problems of overcrowded cities, air and water pollution, solid waste disposal, noise pollution, traffic congestion, and insecticide poisoning, the prospect of meeting the demands of another 100 million Americans in the next 30 years can hardly generate optimisin for the environmental quality of the future.

\section{The Call for Fertility Control Now}

The pressure population growth unceasingly exerts on our environment and the magnitude of probable future growth in historical perspective, provides the setting for the critical question: How strong is the need for fertility control in the United States? Two separate lines of argument support the proposition that the need is compelling and immediate.

First, the world population problein could not safely be ignored by the United States even if it did not affect this country. There are strong indications that within 50 years the world will experience massive fainines, unlike any man has known historically in that they will be derived from Malthusian limits rather than short-terin catastrophic occurrences

cational facilities, industrial plants, every 20 to 35 years. Add to this the fact that these people have rising expectations, which often cause political turmoil when frustrated, and it becomes readily apparent that until this pattern of population growth changes, attempts to develop most of these countries are futile. See P. EHRIICH, supra note 7 , at $22-23$.

34. See N.Y. TIMES INDEx, 1968, at 403; See also Snow, Excerpts from John Findley Green Lecture at Westminster College, N.Y. Times, Nov. 13, 1968, at 29, cols. 1,7 ; N.Y. Times, July 9, 1968, at 3, col. 2.

35. See Keyfitz, supra note 28, at 43, 54.

36. See note 29 supra.

37. See P. Ehrich \& A. EgrLich, supra note 2, at 39. 
such as wars or unusual weather conditions..$^{38}$ Some authorities believe these waves of mortahty will occur within five to ten years. ${ }^{30}$ Already the world seems poised for these disasters, as large proportions of the world's population are currently underfed. ${ }^{40}$ While these famines will undoubtedly be concentrated in the underdeveloped nations, the chaos they cause will not be restricted to the political boundaries of the countries involved. One reason for this is the increased likelihoood of wars between those nations whose populations are starving and those that have both food and inaterial luxury. Even if such wars do not occur, famines greatly increase the chances of worldwide ecological catastrophe which would affect both rich and poor nations. One very possible example would be the death of the ocean's intricate and important food chain brought on by the over-use of ever-more powerful pesticides in the agriculture of starving nations in an attempt to increase yields. Another reason the population problems of the undeveloped world cannot be ignored is that our industry is heavily dependent on imports of many critical minerals and other raw materials. ${ }^{41}$ Should starving nations become unable or unwilling to supply our need for raw materials, economic chaos of solne degree would result in the United States.

World population control, achieved by means of fertility control, is very much in the best interest of the Umited States for the reasons discussed above. ${ }^{42}$ It is also highly probable that few nations will have either the will or the ability to end their population growth without strong guidance and leadership from the Umited States. This means that if the United States is going to attempt to aid in the solution of the world population crisis, it inust take steps to end its own population growth. Officials in some countries still beheve population growth is essential to development, ${ }^{43}$ a behef which is economically unsound today, but which is supported in their minds by the history of United States' development. To these officials, attempts to foster programs of fertility control abroad, while instituting no such programs at home, must seem particularly offensive. Thus failure to at least attempt to control popu-

38. See id. at 67-69, 98-101.

39. See W. Paddock \& P. Paddock, Famine-1975! (1967).

40. See P. EhrLICH \& A. EhrLICH, supra note 2, at 67-69.

41. Id. at 58-63. One good example is that in 1966 we mined $52,209,000$ tons of iron ore and consumed 131,314,000 tons of steel. Id. at 61 .

42. This assumes that the United States will never take a genocidal attitude of eradicating poverty by eradicating the poor. Aggressive use of military strength could probably solve the problems of non-cooperation and possibly even dangerous environmental practices, bnt it would also create problems in that other super powers might not allow this conntry to pursue such a coercive course and this sort of practice is repugnant to the ideals of our society.

43. P. EHRLICH \& A. EHRLICH, supra note 2 , at 248-49, 
lation here may resign the United States and the world to whatever chaos may follow as a consequence of uncontrolled population growth.

A second, and more direct, reason in support of attempting to control fertility in the United States now is that the chances are dangerously great that the combination of population growth and excessive affluence will create an environmental disaster that will control our population in a most unpleasant manner. The threat of the continually increasing use of pesticide chemicals, mentioned above, ${ }^{44}$ is only one of several such disasters toward which population growth pressures this country. Another is the possibility of inassive incidence of respiratory disease due to air pollution. ${ }^{45}$ Air pollution also raises a threat of inadvertent weather modification which could drastically change our environment. $^{48}$ Other possible consequences of continued population growth range from the historically well-known ${ }^{47}$ to the esoteric creations of our modern technology. ${ }^{48}$

These possibilities may present a compelling case for fertility control now. The United States will probably add 100 million more people by the year $2000^{49}$ and even if fertility is controlled ${ }^{50}$ by 1980 , it would

44. See text accompanying notes 18-22 supra.

45. See text accompanying notes 14-15 supra.

46. See Council on EnVIRonmental Quality, Environmental Quality-1970, at 93-104 (1970).

47. For example, lack of adequate food supplies, fuel and housing. See notes 4-22 supra and accompanying text.

48. For example, genetic damage due to increased exposure to radioactivity as atomic blasts are used to aid in the extraction of minerals and fuels. Such methods are being considered for future use to offset the depletion of easily available sources of many mineral resources. Plysicist William Pollard recently predicted that "by this century's end freslı water, petroleum and natural gas, copper, lead, tin, chromium, manganese and iron ore will be in critically short supply." Anspacher, Man's Dismal Outlook, S.P. Chronicle, Nov. 21, 1969, at 2, col. 1. Even if Pollard is far too pessimistic, other experts agree that in order to meet the demand of the near future, the Urited States will have to rely on new technology in finding new deposits and substitutes. See, e.g., Lovering, Mineral Resources from the Land, in REsouRCES AND MAN 109, 128-33 (1969). New techniques often require a great deal of time for development and perfection before they are safe for practical use. Presently "there are many signs that technology is not keeping pace with increasing costs of extraction in the United States." Id. at 130. Thus it is possible that future scarcity of minerals, caused partly by population growth, will create economic pressure to take risks such as might accompany use of atomic blasts to aid in mineral extraction. See CouncIL on ENvIRonMentar QualITY, supra note 46, at 140-47. Large increases in mortality could also result if anything were to go wrong with nuclear reactors built to meet the rapidly expanding demand for power.

49. See text accompanying notes 36-37 supra.

50. "Fertility control" means, in essence, that each woman shall have no more than two children. If eacli mother has only two offspring she only replaces herself and her mate and no population growth occurs. Actually this limitation will eventually cause population to slowly decline because all women will not produce two children, and death before child bearing age will take a toll. But considering the present crowded 
take until nearly 2000 A.D. for the population to stop growing:

[P]opulation is not like water issumg from a tap-to be turned off at will when the desired level has been reached. To a unique degree, demographic conditions at any point in time are determimed by what has gone on before. A pertinent illustration is the fact that even if, starting tomorrow, women were to have no more than two children apiece, total world population would continue to rise substantially for another two decades. Why? Because all the world's mothers for the next 20 years have already been born and the numbers entering the childbearing ages are rising year by year. ${ }^{51}$

Thus there is a substantial lag between the institution of fertility control and the point when zero population growth is reached. The existence of this lag is a major factor in support of the argument that the government presently has a coinpelling state imterest in the institution of fertility control.

The lag is also part of the reasoning process which has led many reputable and highly regarded sources within the scientific community to urge fertility control now. One notable example is the Committee on Resources and $\mathrm{Man}^{52}$ of the National Acadenn of Sciences-National Research Council which recently recommended

$[t]$ hat efforts to limit population increase in the nation and the world be intensified by whatever means are practicable, working toward a goal of zero rate of growth by the end of the century . . . . [P]opulation control is the absolute primary essential without which all other efforts [to insure security against resource depletion] are nullified. Our Departments of State and of Health, Education, and Welfare should adopt the goal of real population control both in North

conditions in most contries (including the United States), this is not to be feared for many years. See note 57 infra.

51. Address by L. Day, American Association for the Advancernent of Science Symposium, Boston, Dec. 30, 1969, at 5, on file with the California Law Review and the Ecology Law Quarterly. Mr. Day's conclusion is based upon a two child limit per woman. Obviously growth would slow down much faster if only one child were allowed and would stop immediately if no more children were to be born until the optimum population size was reached. But the latter measures are less likely to be accepted since they are highly oppressive and they impose a burden which only one particular generation must bear.

52. The Committee on Resources and Mau of the Division of Earth Sciences, National Academy of Sciences-National Research Council, is chaired by Preston Cloud of the Department of Geology, University of California at Santa Barbara. Other inembers are Marston Bates of the Department of Zoology, University of Michigan; John D. Chapinan of the Department of Geography, University of British Columbia; Sterling B. Hendricks of the Mineral Nutrition Laboratory, U.S. Department of Agriculture; M. King Hubbert of the Geological Survey, U.S. Department of the Interior; Nathan Keyfitz of the Departmeut of Demography, University of California at Berkeley; Thomas S. Lovering of the Department of Geology, University of Arizona; and William E. Ricker of the Nanaino Biological Station, Fisheries Research Board of Canada. Resources AND MAN ii (1969). 
America and throughout the world. Ultimately this implies that the community and society as a whole, and not only the parents, must have a say about the number of children a couple may have. ${ }^{58}$

Such a call for government action to achieve zero population growth by the year 2000 raises the possibility that the federal government may enact legislation in this area in the near future. The contentions that this goal will require direct government intervention ${ }^{54}$ and that action must be taken soon suggest that a program of direct control of family size may be among the measures considered by Congress. Aside from the obvious political problems which such legislation would face, ${ }^{55}$ it is almost certain to raise serious constitutional questions. Thus, it is profitable to explore and analyze the constitutional issues involved and suggest factors which the legislature and courts should consider in passing on direct control legislation.

II

\section{DIRECT GOVERNMENT CONTROL OF FAMILY SIZE}

\section{A. Methods of Direct Control of Family Size}

If Congress could legislate that families shall henceforth not exceed two children and achieve this goal without any effect on individual freedom other than the loss of the legal right to have more than two children, the constitutional inquiry would be simplified. It would involve a balancing of only one individual interest-the imdividual's concern with his right to reproduce without limit-against society's concern with overpopulation. The question would then be which concern is likely to be considered more important by the courts. The matter is complicated, however, by the present state of birth control technology. An examination of the methods within the realm of present possibility requires the conclusion that any attempt to insure that couples have only two offspring is likely to affect their lives in ways which go beyond the desired effect of the legislation. An attempt should be made to insure that these adverse effects are kept to a minimum.

53. Id. at 11.

54. This contention raises the complex question of what is necessary to achieve zero growth. This will be another area of contention in a constitutional dispute because the proponents of a program of compulsory control may be required to prove there is no better effective alternative means of reaching the goal of zero growth. For a discussion of this question see notes 50 supra and 56 infra.

55. The Catholic Church, which opposes the use of most voluntary forms of contraception, would undoubtedly vigorously oppose any compulsory family limitation, and it seems likely that opposition would not be limited to this source. This discussion assumes that this obstacle is overcome and considers the constitutionality of such a law if it were in fact enacted. 
One way to achieve fertility control ${ }^{58}$ would be to require sterilization of one or both parties after a couple has had two children. ${ }^{67}$ Such

56. For purposes of this discussion, control means compulsion. The need for compulsion would, of course, have to be proved as an element of the need for-or compelling state interest in-fertility control should any particular program be subjected to constitutional attack. It would seem that in order to show the need for compulsion, the government would have to prove that it could not achieve zero growth by less than coinpulsory means in time to avert disaster.

It is possible that the question of the necessity for compulsion would receive more attention than the principal question of the need for government fertility planning. Opponents of compulsory measures could point to the government's potential ability to lower fertility by repealing abortion restrictions, by promoting and subsidizing contraceptive research and greater public knowledge of contraceptives, and by making strong and sincere appeals to the public for responsibility in breeding. Possibly the strongest argument the opponents of compulsion can make is to point out the success of Madison Avenue advertisers in shaping public opinion on other issues, and to suggest that governmental use of these methods could control fertility without compulsion.

The proponents of coinpulsion can, however, muster a variety of arguments to support the contention that only compulsory action is sure to bring about the desired result. For example, denographic studies have shown rather conclusively that birth rates correspond to the desires of the average parent with respect to family size rather than to the availability of contraceptives or abortion. See Blake, Population Policy for Americans: Is the Government Being Misled?, 164 SCTENCE 522 (1969). Thus, while legalization of abortion and wide dissemination of contraceptives nay lower fertility to some extent, the historical fact that zero growth has never occurred-either in this country [see note 29 supra] or in Japan where abortion has been made legal [see note 30 supra]—suggests that these measures will fail to stop population growth in the future.

The argument that campaigns of mass propaganda may achieve a zero growth rate without compulsion can be met with the counter-argument of the notable lack of success of such campaigns to change deeply held beliefs in any short period of time; an argument perhaps buttressed by the lack of success of the mass media approach in the last national elections.

Perhaps the issue will turn, in final analysis, on the ability of the proponents of the direct control statute to establish the need for achieving a zero growth rate. A compulsory program certainly has a higher probability of achieving a zero growth rate than a non-compulsory program; and the greater the need for accomplishing the desired results, the stronger the argument that the means which has the highest probability of success are necessary. The necessary wait of 20 to 30 years before zero growth is reached [see text accompanying notes 49-51 supra] neans that the failure of a noncoinpulsory plan inreases the chances of environmental disaster. Furthermore, if a non-compulsory program failed to achieve the goal of averting disaster, the compelling state interest in the program would not exist [see note 100 and text accompanying notes 96-104 infra] and the program could be subject to constitutional attack.

There is also an argument that a compulsory plan is actually desirable. A compulsory system can be designed to affect every citizen equally while a program of fertility reduction by use of propaganda can be mamipulated by its administrators to effect one group more strongly than another. This is the principal criticism which minority leaders currently level at government sponsored family planning programs. See Hallow, The Blacks Cry Genocide, 208 The Nation 535 (1969).

57. The two-child limit is chosen for purpose of discussion largely because the two-child family is so frequently spoken of as the ideal when population control-as opposed to family planning-is discussed. E.g., P. EnRLICH, supra note 7, at 175. See note 50 supra for a brief discussion of the impact of a two child linit on population change. 
a system would be safe, highly effective, and have no physical effect on the individual other than the desired one: to render him incapable of procreation. ${ }^{58}$ However, any plan utilizing sterilization as its sole means of operation may lead to harsh results in that the couple may be left childless. ${ }^{59}$

Another possible imstrument of direct control is abortion. The main advantage of abortion is that it is very safe ${ }^{60}$ and leaves a woman fertile so that if reproduction later becomes permissible it is also possible. This solves the major problem raised by sterilization, but it also creates at least one problem of its own: enforcement. If the government relies upon compulsory abortion to end all third pregnancies, some women might attempt to hide their pregnancy until birth. Criminal penalties for such behavior, or required sterilization after the third birth, would act as a strong deterrent to this type of activity.

Other presently available birth control measures (condoms, I.U.D.'s, oral contraceptives) are not likely to be given serious consideration as tools of direct control because their use is so personal and none is 100 percent effective. ${ }^{61}$ Still, these methods of contraception can be valuable to a direct control program in that their availability al-

58. The sterilization operation for males, known as the vasectomy, is a simple operation which ordinarily requires only a local anesthetic. It involves the prevention of sperm from entering the semen and does not impair sexual drive or enjoyment. It should never be confused with castration. The risk of death from the operation is almost non-existent. L. LADER, ABORTION 161-62 (1966).

The female operation, known as the salpingectomy, involves the ligation of the fallopian tubes which carry the egg from the ovary to the uterus and ordinarily requires an abdominal incision. Since no hormone-producing organs are removed or altered, sexual response is left unaffected by the operation. Chances of inortality are slim as the operation is no more complex than an appendectomy. Also, the operation is safest directly after childbirth when the uterus is enlarged. If caesarian section is required, the tubal bitigation adds nothing to the risk of death. See id.; Forbes, Voluntary Sterilization of Women as a Right, 18 DE PAUL L. REv. 560, 561-62 (1969). The chances of undesirable side-effects to the subject or to the descendants (due to unknown genetic damage) from either operation are very small.

59. The attempt to reverse the salpingectomy by re-attaching the cut ends of the fallopian tube "is roughly comparable to sewing two pieces of soggy macaroni while someone is pulling at each end. Usually it doesn't work." D. REUBEN, EVERYTHING You Always Wanted to KNow About SeX-But Were Afram to AsK 240 (1969). The vasectomy can be reversed in about 40 percent of the cases. Id.

60. "It is now safer for a woman to have a hospital therapeutic abortion during the first trimester than to bear a child." People v. Belous, 71 Cal. 2d 954, 965, 458 P.2d 194, 200-01, 80 Cal. Rptr. 354, 360-61 (1969). In the footnote supporting this statement, the court points out that the only data which shows maternal mortality higher after abortion than after birth comes from Sweden where only 35 percent of all abortions occurred in the first trimester, most of the abortions occurring later in pregnancy. Even in Sweden, however, maternal mortality is only shightly higher after abortion, and in other countries is lower than the mortality rate after birth. Id. at 965 n.7, 458 P.2d at 200-01 n.7, 80 Cal. Rptr. at 360-61 n.7.

61. See P. Ehruich \& A. Ehruich, supra note 2, at 219. 
lows individuals to choose to voluntarily limit reproduction in cooperation with governmental efforts.

Possibly the most feasible solution, given present technology, ${ }^{02}$ would be to set the limit of two children per family, but provide that each person has the malienable right to reproduce himself. When a couple has had two children sterilization could be required unless the woman agreed to voluntarily undergo abortion in the event of an accidental third pregnancy. Stiff criminal penalties would probably minimize deliberate nonperformance on the part of such women. This kind of plan does not solve all the problems and is not offered as an ultimate solution, but it does achieve several important goals: First, it is technologically feasible and has a high degree of medical safety to the individual; second, it allows a significant degree of individual choice while at the same time providing the ultimate sanction of compulsion; and, finally, it treats every nember of the society equally. Thus, it would have the slightest impact on the individual consistent with the goal of limiting births in the manner necessary to achieve zero population growth.

\section{B. Federal Government Power to Control Family Size}

The preceding discussion has assumed that the federal government is the agency through which direct control would be instituted, and as a practical matter, a nationwide program would be needed to achieve any meaningful results. In addition, federal action would be desirable because of its implication for world population control. ${ }^{03}$ However, since the federal government is a government of limited powers, ${ }^{64}$ constitutional authority for direct control legislation must be found within Congress' specific powers.

One of the most important of the enumerated powers is the commerce clause ${ }^{05}$-significant because it has been interpreted broadly

62. The future may bring biological advances which would hclp alleviate some of these problems. One possible aid would be the development of a temporary reversible sterilant which could be administered with careful government control ovcr the reversal mechanism. Even with this sort of system, however, there would have to be sanctions to prevent a black market in the reversal mechanism from developing. Another possibility is the development of efficient and inexpensive sperm banks (and perhaps ovary banks) so that sterilization would not mean the end of one's reproductive capability if reproduction later became desirable and permissible. Still another aid would be development of methods to predetermine the sex of a child. This would allow parents to have at least one child of the sex they prefer even though they are limited to two children in their family.

63. See text accompanying notes $42-43$ supra.

64. "The powers not delegated to the United States by the Constitution, nor prohibited by it to the States, are reserved to the States respectively, or to the people." U.S. Const. amend. X.

65. The Congress shall have Power ... . [t]o regulate Commerce . . . among the several states . . . U U.S. CoNST. art. I, \& 8. 
enough to give Congress the sweeping national powers it needs to regulate our modern economy. ${ }^{B 8}$ While this power was limited by the Supreme Court in the first third of the twentieth century, ${ }^{67}$ since the 1937 decisions in NLRB v. Jones and Laughlin Steel Corp. ${ }^{68}$ and United States v. Darby ${ }^{69}$ there has been little doubt that

[t]he constitutional grant of power over commerce [is] now interpreted as enabling Congress to enact all appropriate laws for the protection and advancement of commerce among the states, whatever measures Congress might reasonably think adapted to that end, without regard for whether particular acts regulated in themselves [are] interstate or intrastate. ${ }^{70}$

The question, therefore, is whether or not fertility control is reasonably adapted to the end of advancing and protecting interstate commerce. At first glance, population control would seem to have just the opposite effect; that is, it would decrease demand and therefore would impede rather than advance commerce. But this is true only in the sense that the word "commerce" may be limited to the traffic of goods and services. Congress has long reserved the power to limit or even prohibit certain kinds of traffic in the imterest of regulating interstate commerce. ${ }^{71}$ Thus, if population growth has a harmful effect on interstate commerce, Congress may legislate to limit the growth of population.

66. See Stern, The Commerce Clause and the National Economy, 1933-1946, 59 HARv. L. REv. 645 (1946). The author notes that Congress made little use of the authority granted by the commerce clause until 1887 [the Interstate Commerce Act, 49 U.S.C. $\S \S 1-27$ (1964)] and 1890 [the Sherman Act, 15 U.S.C. $\$ \$ 1-7$ (1964)]:

[t]he nation was growing, geographically and economically, there was adequate opportunity for men with initiative and ability without the assistance of government, and there was very little demand by the public for the intrusion of government-state or federal-into the world of business and commerce.

Stern, supra at 645. It seems appropriate to note that the end of laissez-faire is also the time noted as the end of the frontier [see note 106 infra], or in other words the beginning of an age when increased population necessarily means increased coinplexity of the economic strncture and therefore increased government regulation of that structure in order that eacis individual is protected.

67. See, e.g., Carter v. Carter Coal Co., 298 U.S. 238 (1936); Haminer v. Dagenhart, 247 U.S. 251 (1918).

68. 301 U.S. 1 (1937).

69. 312 U.S. 100 (1941).

70. Stern, supra note 66, at 946 .

71. See Heart of Atlanta Motel, Inc. v. United States, 379 U.S. 241 (1964); Goocl v. United States, 297 U.S. 124 (1936); Brooks v. United States, 267 U.S. 432 (1925); Caminetti v. United States, 242 U.S. 470 (1917); Hoke v. United States, 227 U.S. 308 (1913); Champion v. Ames, 188 U.S. 321 (1903). One is reminded, when pondering whether fertility control may be related to commerce, of the words of Chief Justice Marshall in Gibbons v. Ogden, 22 U.S. (9 Wheat.) 1 (1824): "Commerce, undoubtedly, is traffic, but it is something more-it is intercourse." Id. at 83, 9 Wheat. at 189. 
Many of the effects of population growth are harmful to interstate commerce. Excessive pressure on natural resource supplies ${ }^{72}$ poses a threat to our future economy. The increasing demand for food creates the need for pesticides, which may cause unexpected damage at a later date. $^{73}$ National Parks deteriorate and become less desirable for vacationing when subjected to over-use. ${ }^{74}$ Finally, the pollution of water and air, exacerbated by increasing numbers of people, factories, and automobiles, affects interstate commerce in many ways. Pollution does not heed state lines and thus one state's irresponsibility nay cause the citizens of surrounding states to suffer the effects of pollution as well: when rivers are polluted in one state, the fishing industries of many states may be eliminated. Congress has recognized this fact in its attempts to deal with pollution by setting up regional districts rather than relying exclusively on state controls. ${ }^{75}$

Congressional power to regulate pollution in this manner was sustained in the case of United States v. Bishop Processing Co. ${ }^{70}$ In that decision, Chief Judge Thomsen of the district court declared that "[ $[\mathrm{t}] \mathrm{he}$ movement of pollutants across a state line ... constitutes interstate commerce subject to the power granted to Congress by the Constitution to regulate such commerce."77 Later in the opinion, Judge Thomsen states the broad principle that "[t]he commerce power may be exercised to achieve socially desirable objectives even in the absence of economic considerations." 78 Thus, even if population control seems only tangentially related to the movement of goods and services across state lines, so long as it is aimed at achieving a socially desirable objective-a livable and pleasant environment-it need not be directly related to economic matters. For these reasons, in the absence of a reversal of the judiciary's hands-off position with regard to the congressional commerce clause power, it seens likely that the Court will find that constitutional authority for federal regulation of family size exists within the commerce clause. This, of course, does not end the consti-

72. See text accompanying notes 7-17 supra.

73. See text accompanying notes 18-22 supra.

74. See R. RIENOW \& L. RIENOW, supra note 8, at 59-64.

75. See e.g. the Air Quality Act of 1967, 42 U.S.C. $\$ \S 1857-18571$ (Supp. V, 1970). In particular, section 1857d provides the Secretary of Health, Education, and Welfare the power to promulgate standards for a state if the state refuses to bring its own standards up to the level deemed necessary by the Secretary. This statute is similar to the direct control statute under consideration here, in that the states are encouraged to act on their own just as the individual is encouraged to linit his family, and federal control is exercised only as a last resort.

76. 287 F. Supp. 624 (D. Md. 1968).

77. Id. at 629 .

78. Id. at 630 . Judge Thoinsen cites the cases in note 71 supra in support of this statement. 
tutional argument against a direct control statute. The real battle may be expected over whether such a statute conflicts with personal rights and liberties guaranteed by the Bill of Rights.

\section{Personal Liberties and Population Control}

Postulating that the government takes the position that society must set a compulsory limit on family size ${ }^{78}$ in order to achieve a goal of zero growth, it is clear that direct control will mean a substantial diminution in personal freedom. The Bill of Rights presents a potential obstacle to any program which removes froin the individual the right to make the decision of how many offspring to produce. This section will examine the most likely avenues of attack on a direct control program and will attempt to evaluate the possible outcome of a constitutional challenge.

\section{Free Exercise of Religion}

The fact that a large minority of the population of the United States belongs to a religious faith which proscribes the use of birth control drugs or devices even on a voluntary basis presents one obstacle to any direct control statute. The constitutional question is whether compelled limitation of family size violates the free exercise clause of the first amendinent. ${ }^{80}$

The Supreine Court has generally distinguished between government regulation of an individual's beliefs and his actions. ${ }^{81}$ Thus while the state cannot prescribe what an individual should believe, ${ }^{82}$ when the individual's rehgious beliefs cause him to act in a way detrimental to the interests of society as a whole, the state can restrict that person's freedom of action without violating the free exercise clause. ${ }^{83}$ Such restric-

79. For a discussion of the possible arguments on either side of this crucial issue see note 56 supra.

80. "Congress shall make no law respecting an establishment of rehion, or prohibiting the free exercise thereof . . .." U.S. CoNST. amend. I.

81. See Braunfeld v. Brown, 366 U.S. 599, 603-04 (1961).

82. West Virginia State Bd. of Educ. v. Barnette, 319 U.S. 624 (1943).

83. The most famous in this line of decisions are the polygamy cases in which members of the Mormon Church were convicted of the crime of polygamy despite their claim that their religious beliefs required them to practice polygamy. Reynolds $v$. United States, 98 U.S. 145 (1878). Later this rule was extended when the Court upheld the conviction of a Mormon for conspiracy to register to vote when not entitled to do so because of his membership in an organization which taught and encouraged polygamy. Davis v. Beason, 133 U.S. 333 (1890). While the Mormon Church finally gave up the teaching of polygamy [Late Corp. of the Church of Jesus Christ of the Latter Day Saints v. United States, 136 U.S. 1 (1890), decree entered, 140 U.S. 665 (1891) was the force which caused this result], a small group of fundamentalist Mormons have continued to face criminal prosecution for their beliefs. See, e.g., Cleveland v. United States, 329 U.S. 14 (1946). 
tions require that an accommodation be made between an individual's right to freely exercise his religious beliefs and the state's need to protect the public health, safety, and peace. A long line of cases appears to test legislation in this area by determining whether there is a rational basis for deciding that regulation of the activity would achieve a legitimate state interest. ${ }^{84}$ The case of Sherbert $v$. Verner, ${ }^{85}$ however, casts doubt upon the continued validity of this test.

In Sherbert, a Seventh Day Adventist refused to be "available for work" on Saturday due to her observance of her religion's Sabbath. According to the State Employment Security Commission's interpretation of the South Carolina Unemployment Compensation Act, this made her ineligible for unemployment benefits. The Supreme Court of South Carolina affirmed this interpretation and held that the statute did not restrict her freedoin of religion " "nor [did] it in any way prevent her in the exercise of her right and freedom to observe her religious behefs in accordance with the dictates of her conscience." "86 The United States Supreme Court reversed the decision of the state court holding that in order for the regulation to stand, the state must have a compelling interest in the regulation in question, or more precisely, the Court must find the state's interest to be compelling. ${ }^{87}$ The Court did not find the interest of South Carolina compelling enough to allow the state to infringe on the religious actions of the individual..$^{88}$

The primary importance of this case with respect to the direct control statute is that the government may have to show a compelling state interest in fertility control and also that fertility control cannot be achieved without infringing on individual actions based on rehgious belief. ${ }^{89}$ This judgment must be tempered, however, by the Court's implication that it considered the long line of cases which had used the rational basis test still valid since "[t]he conduct or actions so regulated

84. See, e.g., Braunfeld v. Brown, 366 U.S. 599 (1961); Prince v. Massachusetts, 321 U.S. 158 (1944); Reynolds v. United States, 98 U.S. 145 (1878).

85. 374 U.S. 398 (1963).

86. Id. at 401.

87. Id. at 406 .

88. Id. at 408.

89. The Court in Sherbert made it clear that a showing of no effective alternative would be necessary to show a compelling state interest in the chosen regulation. Id. at 407. The discussion of the need for compulsion [note 56 supra] bears on this issue although it is possible that with respect to religion, a program of government propaganda as an alternative to compulsion might encounter constitutional difficulty from the establishment clause if the government found it necessary to actively campaign to induce people to forsake particular religious teachings. If this were the case, and if the Court found the need for fertility control to be compelling, presumably the Court would balance the two possible programs, taking into consideration probable effectiveness and gravity of the variance from constitutional standards for each of the programs. 
[in those cases] have invariably posed some substantial threat to public safety, peace or order." ${ }^{30}$ In other words even if the rational basis test is gone, many of the cases decided under it are still valid because they probably would have met the test of a compelling state interest as well. This would work in favor of direct control. The government would find it far easier to slow that uncontrolled fertility is a substantial threat to public safety, peace and order than to show that one group's refusal to work on Saturdays represents such a threat; the former may bring environmental disaster as compared to the latter's threat of slightly higher unemployment costs. The Court in Sherbert may liave really decided that the state must make an exception for rehigion because there had been no clear showing that any substantial harm to the state's interests would occur thereby. ${ }^{91}$ The government can easily show that an exception in the direct control statute for a substantial percentage of the population who believe they must not interfere with natural conception and birth would greatly hinder, if not totally destroy, the objective of stabilization of population size. ${ }^{92}$

The rationale that government could not achieve its legitimate goal if it were forced to make an exception was used by the Court in Sherbert ${ }^{33}$ to distinguish the case of Braunfeld v. Brown. ${ }^{94}$ In that case, the state's goal was to provide a uniform day of rest for its citizens by enacting Sunday closing laws. If this goal was strong enough to meet the compelling state interest test, and the Court in Sherbert implies that it was, ${ }^{95}$ it seems highly probable that governmental interest in preventing large imcreases in mortality brought on by population pressure would also meet the standard.

In attempting to convince the Court that there is a compelling state interest in direct control of family size, the governinent's counsel could make four basic arguments. First, counsel could present all the available scientific data tending to show that population growth creates un-

90. 374 U.S. at 403.

91. See Note, A Braunfeld v. Brown Test for Indirect Burdens on the Free Exercise of Religion, 48 MiNN. L. REv. 1165, 1177-78 (1964), which points out that the exception could only hinder the state's purpose if it was such an economic burden that the state could not afford to continue the program. In Sherbert, the state showed no such burden. 374 U.S. at 407.

92. It is also possible that to make an exception for some on religious grounds in such a sensitive area would be a violation of equal protection. If, for example, there is a constitutional right to unlimited procreation which the Court finds can be limited only because the government has a compelling state interest in doing so, then to return this right to some citizens on grounds of rehigion would be to deny equal protection to all those who do not embrace the same behefs.

93. 374 U.S. at 408-09.

94. 366 U.S. 599 (1961).

95. 374 U.S. at 408. 
ceasing pressure toward irreparable environmental harm and consequently toward greatly increased death rates. ${ }^{96}$ Projections of probable growth by 2000 if fertility is not controlled, and the probable environmental impact of that growth, ${ }^{97}$ could be used to argue that zero growth by the year 2000 is a legitimate and compelling goal. ${ }^{88}$ Second, the advocates of direct control could attempt to show that in order to achieve zero growth by 2000 , while maintaining the right of each individual to reproduce himself, control of family size must begin now. ${ }^{90}$ This involves the related argument that if government is forced to wait until disaster is imminent before it can control fertility, its action in doing so may be too late, or the only choice may be to ban reproduction coinpletely for a number of years. ${ }^{100}$ In order to avoid such a dilemma, the government could argue strongly that present action is necessary. Third, the government would have to show that whatever plan is adopted is the best one available to it. Thus if compulsion is a part of the program, its use must be shown to be necessary to achieve the goal of zero growth. ${ }^{101}$ Finally, government counsel could argue that any uncertainties in the scientific data predicting future events must be construed in favor of direct control rather than against it. ${ }^{102}$ This is not to say that the government need not show clearly that population growth is a danger, but rather that once it has been shown that continued growth must inevitably lead to disaster, then the uncertainty as to when disaster will strike should be resolved in favor of the regulation. The reason for this argument is apparent if we consider the consequences of error on either side. If the Court were too pessimistic, allowing imposition of direct control too early, then for some uncertain period of time constitutional rights, which almost certainly must eventually give way to regulation anyway, would be infringed without an actual compelling state

96. See text accompanying notes 7-35 supra.

97. See text accompanying notes 44-49 supra.

98. See text accompanying notes 51-53 supra.

99. See text accompanying notes 49-51 supra.

100. It is, of course, not absolutely certain that without fertility control mortality will rise sharply in the year 2000 . However, since the finite size of the earth rules out the possibility that mortality will not eventually increase if fertility is not controlled [see notes 7-22 supra and accompanying text] the only uncertainty which plagues our imperfect view of the future is whether disaster will strike before or after the year 2000. If disaster is due in or before 2000 , there is surely a compelling interest in achieving zero growth in order to minimize the suffering and prevent further disaster in the future. If the disaster is actually not due until after 2000, the government might not have a compelling interest in achieving a zero growth rate now. The burden of proof may be all important here. It can also be argued that the effect of the institution of fertility control before it is absolutely necessary to avoid disaster is beneficial to the solution of many of our present societal problems.

101. See note 56 supra for a discussion of the need for compulsion.

102. See note 100 supra. 
interest. But at the same time, because of decreased growth, the quality of the environment and the prospects for future prosperity would be improved. ${ }^{103}$ On the other hand, if the Court were too optimistic, imposing direct control too late, the consequences would be devastating. ${ }^{104}$ Tremendous sacrifices of life and property would be exacted of a future generation for the meager gain of a few more years of unrestricted procreation. ${ }^{105}$ Thus in order to minimize the risk, the government would argue, we should construe uncertainty im favor of direct control.

In support of the argument that government has a compelling state interest in fertility control the advocates of direct control may also cite the historic trend of loss of individual liberty caused by population growth. ${ }^{106}$ This trend continues as long as population continues to grow. To illustrate this point, the frontiersman probably paid little heed to the things he dumped into the rivers because there was enough water to dilute his waste. Today such activities must be carefully regulated or the persons downstream will soon drink poisoned water. More regulations require more governmental authority and more taxes to support an ever growing bureaucracy. And as the governmental system gets bigger and inore complex, the individual becomes smaller and more insignificant-his voice is no longer heard by the many politicians who purport to represent him. Often this may not be because the representative does not care to listen, but rather because with several million people in his district he only has time to listen to some of the many points of view. Certainly there is no enunciated constitutional protection against erosion of voting power or diminution of economic freedom due to increasing nuinbers, but the fact that zero growth would alleviate these problems, or at least prevent further damage, might not be lost on the Court. By himiting certain constitutional rights now, when it

103. See note 106 infra and accompanying text.

104. See text accompanying notes $44-48$ supra.

105. This raises the question of how much, if anything, we owe to future generations. It would be possible for the Supreme Court to design a new constitutional standard for cases in which future well-being is a factor. The goal of securing the blessings of liberty to ourselves and our posterity, contained in the preamble to the Constitution, indicates that the framers hoped the Constitution would protect future generations as well as their own. But even if this inust be rejected as calling for an amorphous and unworkable standard, the fact that a large percentage of our population can presently expect to be alive in the year 2000 shows that fertility control need not be supported by such a standard if the scientific evidence tending to show possible disaster before that time is valid.

106. The loss of econouric and social freedom as a consequence of imcreasing population requiring increasing regulation is generally apparent from a reading of historical accounts dealing with the period from 1890, when the last of the frontier was settled, to the present. See generally W. WeBB, The Great Frontier 103-39, 413-18 (1952). Moore, Legal Action to Stop Our Population Explosion, 12 Clev.-Mar. L. REv. 314, 321-22 (1963) gives direct considerations to this particular problem. 
appears that they must be limited eventually, the Court would be able to laalt this historical trend of encroachment on individual liberties due to increasing numbers.

\section{The Right to Marital Privacy: Family Rights}

Probably the most pertinent case thus far decided by the Supreme Court, with respect to population control, is Griswold v. Connecti$c u t,{ }^{107}$ even though none of the Justices seems to have given any thought to the problem of overpopulation in this decision. ${ }^{108}$ This case is, however, both the foremost legal authority concerning contraception, and also an important enunciation of a new field of individual rights which may have a marked effect on population control legislation.

By a vote of seven to two, the Court in Griswold struck down a Cormecticut statute which made the use or aiding in the use of contraceptives a crime. Quickly dispensing with the issue of standing to sue, ${ }^{100}$ the opimion of the Court based its reversal on a new and rather vague expansion of the fourteenth amendment due process clause. Justice Douglas' opinion, ${ }^{110}$ enunciates a rather new concept concerning the Bill of Rights-that the first, third, fourth, and fifth amendments each have a "penumbra where privacy is protected from governinental intrusion." the existence of this penumbral right of privacy. ${ }^{113}$ Justice Douglas

107. 381 U.S. 479 (1965).

108. The fact that the Court did not discuss population control is not really surprising; until recently virtually everyone believed the population explosion was not a problen in the United States. Also, at the time, family planning was seen as the solution to population growth problenus and thus this decision seemed to aid in controlling population. Now it is more widely recognized that because family planning begins with the premise that husband and wife shall decido how many offspring to have, it is possible that family planning can be in direct opposition to population control when parents generally want more children than is desirable for society as a whole. See generally P. EHRLICH \& A. EhRLICH, supra note 2, at 233-58.

109. The defendant was a doctor who had provided a married couple with contraceptive information and devices. Standing was found on the grounds that unless the doctor could raise the constitutional rights of the people to show that tho act he had been convicted of assisting was not or could not be a crime, he would be deprived of a valid and potentially valuable defense. 381 U.S. at 481 . A similar previous case where standing has been denied, Tileston v. Ullwan, 318 U.S. 44 (1943), was distinguished on the ground that the plaintiff in Tileston sought a declaratory judgment in favor of others whon he represented.

110. Joined in by Justices Clark, Goldberg, Breunan, and Chief Justico Warren.

111. 381 U.S. at 483-84.

112. Id. at $484,487-99$.

113. "The enumeration in the Constitution, of certain rights, shall not be construed to deny or disparage others retained by the people." U.S. Const. amend. IX. Dixon, The Griswold Penumbra: Constitutional Charter for an Expanded Law of Privacy?, 64 Mich. L. REv. 197, 207 (1965), provides an interesting note on how the concurring opinion of Justice Goldberg further brought to life this relatively forgotten provision. 
concludes that marriage is "a relationship lying within the zone of privacy created by [the combined penumbrae of] several fundamental constitutional guarantees." 114

Justice Goldberg, im his concurrimg opinion, ${ }^{115}$ would go further than simply striking down the Connecticut law on the basis of a right to marital privacy. He would recognize a fundamental right of every citizen "to marry, establish a home and bring up children" "116 and would base that right on the ninth amendment. Arguably this right might include the decision of how many children to have. ${ }^{117}$ Justices Harlan and White each wrote concurring opinions. In common with the three justices represented by the Goldberg opinion, each would recoguize the existence of constitutionally protected marital rights, but both objected to the Goldberg and Douglas theoretical basis for the rights. ${ }^{118}$ Thus, Griswold represents a recognition by seven justices of the existence of an as yet not clearly defined constitutional right involved in the marital or family relationship. Two theories attempting to define the limits and elements of this right are represented by Justice Douglas' theory of marital privacy and the marital-family rights theory espoused by Justice Goldberg.

Looking first at the latter theory, Justice Goldberg goes directly to the central issue concerning the direct control statute's constitutionality: "[s]urely the Governinent, absent a showing of compelling subordinating state interest, could not decree that all husbands and wives must be sterilized after two children have been born to them."119 This dictum emphasizes that the direct control statute could be held constitutional even if it did conflict with an otherwise constitutionally protected right: Control of population size can be a compelling subordinating state imterest. The similar terminology strongly suggests that a direct control

114. 381 U.S. at 485 .

115. 381 U.S. at 486 (Warren, C.J., and Brennan, J., concurring).

116. 381 U.S. at 488, quoting Meyer v. Nebraska, 262 U.S. 390, 399 (1923).

117. See text accompanying note 119 infra.

118. Justice Harlan specifically disagreed with the doctrine of limiting the fourteenth amendmeut due process clause to the rights enunciated in the first eight amendments; for him, due process protection against state action should go further than the Bill of Rights and this is a case in which it does. 381 U.S. at 499 . Justice White also agreed that the fundamental rights related to marriage and the family spring directly from the due process clause, and not froin the Bill of Rights. Id. at 502. But though the three justices involved in the Goldberg opinion disagree with Harlan and White as to how the marital rights came about, the fact remains that five justices agreed that those rights exist.

119. Id. at 496-97 (emphasis added). See also People v. Belous, 71 Cal. 2d 954, 458 P.2d 194, 80 Cal. Rptr. 354 (1969): "The fundamental right of the woman to choose whether to bear children follows from the Supreme Court's and this court's repeated acknowledgment of a 'right of privacy' or 'liberty' in matters related to marriage, family, and sex." Id. at 963, 458 P.2d at 199, 80 Cal. Rptr. at 359. 
statute would be judged by the same standards used for determining whether the statute can survive challenge under the free exercise clause. ${ }^{120}$

It is not completely clear, however, whether Justice Goldberg's vaguely defined marital and family rights include the right to unlimited procreation. ${ }^{121}$ Clearly, one family right which is not protected against legislative control is the right to decide how many spouses to have. ${ }^{122}$ By custom Americans have one spouse and many children but there would seem to be little difference between legislative control of the number of spouses and the number of children.

The opinion of the Court used an entirely different theory, and it is that theory which must be considered as the law created by this case. The Connecticut statute was held to violate the Constitution not because it regulated the marital relationship, but because its enforcement would violate the privacy of that relationship. This right of privacy appears to deal with how a regulation is instituted rather than whether or not it should be. For example, Justice Douglas referred to the Connecticut statute as "a law which, in forbidding the use of contraceptives rather than regulating their manufacture or sale, seeks to achieve its goals by means having maximum destructive impact upon [the marital] relationship."123 Justice Douglas also emphasizes the gravity of the contemplated invasion of privacy in this particular case: "Would we allow the police to search the sacred precincts of marital bedrooms for telltale signs of the use of contraceptives? The very idea is repulsive to the

120. See text accompanying notes 96-106 supra for a discussion of the arguments in favor of direct control as a compelling state interest.

121. This is true despite the reference to sterilization after two children. 381 U.S. at 496-97. It is possible that Justice Goldberg may not have considered such a measure to be a serious possibility since in the context in which it was spoken, it appears he was attempting to give an example which would shock his audience so that they would agree that a constitutional right to marry and raise a family is needed. While this may mean Justice Goldberg would continue to beheve that his example fits within the framework of marital rights he espoused in Griswold, it does leave room for doubt in the minds of future justices as to whether the dictum should be held controlling. In other words, a future Court may wish to recognize Goldberg's family rights doctrine, but exclude the right to unlimited spouses and unlimited children from the definition.

122. See text accompanying notes 81-83 supra. In order to argue that there is a fundamental right to choose how many spouses to have, one would have to ask a Court to overturn the bigamy statutes of every state. It seems highly unlikely that any Court would take such drastic action. On the other hand, a Court could hold that a fundamental right to unlimited spouses exists but is subject to regulation because government has a compelling state interest in preventing bigamy. Should a court decide to go this far in attempting to make the Goldberg standard all-inclusive, it would find difficulty in rationalizing a compelling interest in preventing bigamy while denying a compelling interest in fertility control aimed at preventing massive mortality.

123. 381 U.S. at 485 . 
notions of privacy surronding the marriage relationship."124 Thus the Court seems to say that marital privacy is the protection afforded the married couple against laws which unnecessarily trespass into the more intimate and personal aspects of the marital relationship.

A direct control program may or may not be affected by the right to marital privacy depending on how broadly the right is defined and on the provisions of the particular program. Should the government counsel be able to convince the Court to adopt a narrow construction of the word "privacy," then so long as the disputed direct control statute avoids provisions which could tempt officials to search the marital bedrooin, ${ }^{125}$ it is probably safe. On the other hand, if the Court adopted a broader construction of the ill-defined term "marital privacy" further questions would arise.

One question might be whether governmental surveillance of family size in order to know when to apply sanctions is a violation of marital privacy. Certamly census taking and the information-gathering accomplished by income tax returns has not been adjudged a violation of privacy. The conjecture that families might try to hide children suggests that government might be tempted to go further in its quest for knowledge than it does for the census, and perhaps even further than for collection of mcoine taxes. But certainly the search would not require intrusion into the sacred precincts of marital bedrooms.

Another question might be whether compulsory sterilization as a sanction is an invasion of marital privacy. An affirmative answer would, in effect, equate marital privacy with a right to unlimited procreation because sterilization does not effect sexual response-only the ability to reproduce. ${ }^{126}$ Of course it is possible that the Court would interpret marital privacy as the equivalent of a right to reproduce without limit, because inarital privacy was not clearly defined in Griswold. But

124. Id. at $485-86$.

125. See text accompanying note 124 supra.

126. See note 58 supra. Due to the complex psychological aspects of fertility and its relationship to sexuality, this may be somewhat an overstatement because, to some, sex and the marital relationship itself may be meaningless without the ability to procreate. Where this is true, the situation is similar to that discussed with respect to free exercise; that is, that the government might have to show a compelling state interest in fertility control in order to justify failure to make an exception for the individual whose constitutional rights are set aside in favor of societal interests. See text accompanymg notes 85 to 95 supra. Even this argument is subject to attack, however, because in Griswold Justice Douglas implies that regulation of the sale of contraceptives would have been constitutional. 381 U.S. at 485 . Thus the government could have made them unavailable no matter how much some persons pleaded that they had to have them to enjoy a full sexual life, just so the privacy of a marriage was not violated. This is probably the crucial difference between the opinion of the Court and Justice Goldberg's opinion. 
the government should certainly make the argument that marital privacy does not go this far, that the opinion of the Court in Griswold is the only law created by that case, and that therefore the opponents of direct control must show why there should be a constitutionally protected right to unlimited reproduction. If this argument were to fail, and the Court were to decide that in order to regulate the number of children a couple has the government must have a compelling state imterest, then the proponents of direct control could still pursue the argument that fertility control is such an interest. ${ }^{127}$

\section{Direct Control and the Equal Protection Clause}

There are only two Supreine Court cases dealing directly with coinpulsory birth control statutes-Buck v. Bell ${ }^{128}$ and Skinner v. Oklahoma. ${ }^{129}$ These cases provide support for the proposition that compulsory control of fertility is constitutional, but they also provide a warning-that direct control measures must be designed to meet the requirements of the equal protection clause.

Buck v. Bell affirmed the validity of a state law which provided for compulsory sterilization of persons found to be afflicted with hereditary forms of insanity or imbecility. ${ }^{130}$ The decision was based on the rationale that the state had a strong enough imterest in the genetic quality of its population that sterilization of imbeciles was a valid method of achieving eugenic control. ${ }^{131}$ This rationale has been the subject of a great deal of criticism, most of it centered on the argument that "science has not reached the stage in which it can establish a genetic basis for most sterilization laws." 132 Glanville Williams counters this view with the argument that even though the science of genetics may not justify these laws, they serve a useful social purpose in preventing persons who would tend to be incapable of exercising sound discretion and judgment in a parental role froin having children. ${ }^{133}$ Fortunately, this dispute is irrelevant in a discussion of fertility control. The argnment surrounding Buck goes to whether the means selected will achieve the goal of eugenics. Coinpulsory sterilization after two children would most certainly achieve the goal of zero growth, ${ }^{134}$ and thus the controversy will

127. See text accompanying notes 96-106 supra.

128. 274 U.S. 200 (1927).

129. 316 U.S. 535 (1942).

130. 274 U.S. at 207.

131. Id.

132. Clark, Law as an Instrument of Population Control, 40 CoLo. L. Rev. 179, 193-94 (1968).

133. G. Whliams, The Sanctity of Life and the Crminal LaW 85 (1957).

134. See note 50 supra. 
center around the need for fertility control ${ }^{135}$ and the necessity of using a coinpulsory scheme. ${ }^{136}$ Buck is useful to the proponents of direct control because it allows the argument that since compulsory sterilization was allowed for eugenics when its ability to achieve the goal is in question, surely it should be permitted when the goal is population control which can certainly be achieved using this means. ${ }^{137}$

The continuing validity of Buck is open to question on another ground, however, and it is here that the draftsmen of any direct control statute must focus their attention. The Buck Court concluded that the Virginia eugemic sterilization law does not violate the equal protection clause despite the fact that only some members of society are affected by it. ${ }^{138}$ In light of the Supreme Court's increased attention to the equal protection clause, ${ }^{139}$ this conclusion and the Buck decision may be in jeopardy. Skinner v. Oklahoma ${ }^{140}$ provides the first warning of a possible stiffer equal protection requirement.

In Skinner, the Supreme Court considered a law which provided for compulsory sterilization of "habitual criminals"; defined by the statute as persons convicted two or more times of "felomes imvolving moral turpitude."141 Certain felonies, such as embezzlement and tax evasion, were specifically excluded from consideration of a potential subject's record. Thus a person with two larceny convictions could be ordered sterilized, while another with two convictions for embezzlement could not. The Court held that this was a denial of rights secured by the equal protection clause of the fourteenth ainendment. ${ }^{142}$ The Court could find no justification for the different treatment afforded embezzlers and other larcenists. Buck v. Bell was distinguished and commented on with apparent approval. ${ }^{143}$ Thus Skinner stands as a warning that compulsory sterilization statutes must not arbitrarily single out particular individuals for treatment, but it also re-affirms the constitutionality of a program of compulsory sterilization.

Read together, Buck and Skinner support a conclusion that coinpulsory sterilization-and presumably other similar methods of fer-

135. See text accompanying notes 38-53 supra.

136. See note 56 supra.

137. This assumes, of course, that the goal of population control gives government as strong an interest as the goal of eugenic control. See text accompanying notes 38-53 supra for arguments in support of such a finding.

138. 274 U.S. at 208.

139. See, e.g., Levy v. Louisiana, 391 U.S. 68 (1968); Harper v. Virginia Bd. of Elections, 383 U.S. 663 (1966); Brown v. Board of Educ., 347 U.S. 483 (1954).

140. 316 U.S. 535 (1942).

141. Id. at 536 .

142. Id. at 538 .

143. Id. at 542 . 
tility control-is constitutionally permissible so long as the law does not single out any irrationally determined group as the recipients of the procedure. Since the direct control programs discussed in this Comment would apply to every inember of the society without exception, the equal protection objections of Skinner are avoided. Thus Buck v. Bell reinains. ${ }^{144}$

\section{CONCLUSION}

The need for decreased fertility in order to prevent large increases in mortality and in order to maintain at least minimal standards of environmental quality is scarcely subject to dispute. The real questions are when the zero growth rate must be achieved and what means are necessary. This Comment has explored the constitutionality of a program based on the assumption that compulsion is a necessary means to the end of zero growth if the true goal is to avoid increased mortality. Probably the strongest argument against such a prograin is that it nay be possible to control fertility by voluntary means if government acts very soon to educate the people concerning the threat of population growth and to encourage the responsible citizen to limit his family to two children or less. Government can also improve the chances of achieving zero growth without compulsion if it will remove the various impediments to individual family limitation: repeal abortion restrictions, clarify and affirm the legality of sterilization operations, and liberalize regulation of contraceptives. Because the time factor is uncertain, the proponents of compulsion are correct in warning that reliance on voluntary measures is a gainble. If the gainble is won, the right to unlimited procreation will be preserved, but it will be a right which very few will exercise since winning the gainble means, in essence, a voluntary limitation of procreation. While it may seein comforting to have the right, even if widespread exercise of it would bring on disaster, it is worth noting that the fertility control would also guarantee the right to procreate. It would,

144. Since Buck v. Bell, only ten state supreme court cases have been decided regarding the validity of compulsory (eugenic) sterilizatiou laws. Three of the cases have overturned the state laws, but all three of them were concerned with procedural-lack of provision for notice and hearing-rather than substantive issues. In re Opiuion of Justices, 230 Ala. 543, 162 So. 123 (1935); Brewer v. Valk, 204 N.C. 186, 167 S.E. 638 (1933); In re Hendrickson, 12 Wash. 2d 600, 123 P.2d 322 (1942). Of the other seven cases, six relied on Buck $v$. Bell in upholding the state statute involved. State v. Troutman, 50 Idaho 673, 299 P. 688 (1931); State ex rel. Smith v. Schaffer, 126 Kan. 607, 270 P. 604 (1928); State v. Cavitt, 182 Neb. 712, 157 N.W.2d 171 (1968), appeal dismissed for voluntary settlement, 396 U.S. 996 (1970); Clayton v. Board of Examiners, 120 Neb. 680, 234 N.W. 630 (1931); In re Main, 162 Okla. 65, 19 P.2d 153 (1933); Davis v. Walton, 74 Utah 80, 276 P. 921 (1929). The seventh case upheld the statute, but dealt only with procedural provisions. Garcia v. State Dept. of Institutions, $36 \mathrm{Cal}$. App. 2d 152, 57 P.2d 264 (2d Dist. 1939). 
however, set a limit such that each person would have an equal opportunity to have children while still achieving necessary control of births. If the gamble on voluntary measures is lost, the survivors will certainly regret that the chance was taken. The decision whether to rely on voluntary measures or resort to compulsion will be a most difficult one, but it should be made soon in order to allow a maximum amount of time for either program to work. The sooner voluntary measures are taken, the less likely that compulsion will be necessary.

If Congress and the Executive should decide that compulsion is necessary, constitutional issues would arise since individual liberties would be curtailed by such action. The final resolution of these issues is uncertain, but there is a strong argument in favor of the constitutionality based on the purpose of the various individual freedoms- to enhance the quality of life for all those who live under the Constitution. Hence the Court might be willing to uphold those measures which are clearly shown to be not only consistent with, but essential to the long run achievement of that purpose. If the Court is convinced that "population control is the absolute primary essential without which all other efforts are nullified," 145 the Constitution will not be an obstacle to the goal of zero growth, but rather an aid in finding a just compromise between mdividual freedom from oppression by government and societal freedoin from oppression by overcrowding. Only when this compromise is found will the individual once agaim enjoy the environmental quality which the founders took for granted in their sparsely populated world.

William M. Chamberlain

145. RESOURCES AND MAN 11 (1969). 